\title{
Logistic Regression Analysis Of Predictors Of Loan Defaults By Customers Of Non-Traditional Banks In Ghana
}

\author{
Edinam Agbemava \\ Department of Accountancy, Ho Polytechnic, Ghana \\ Israel Kofi Nyarko \\ Department of Marketing, Ho Polytechnic, Ghana \\ Thomas Clarkson Adade \\ Albert K. Bediako \\ Department of Accountancy, Ho Polytechnic, Ghana
}

doi: 10.19044/esj.2016.v12n1p175 URL:http://dx.doi.org/10.19044/esj.2016.v12n1p175

\begin{abstract}
The objective of this research is to identify the risk factors that influence loan defaults by customers in the microfinance sector and to develop a model that links these factors to credit default by customers in the sector. Data from a microfinance institution based in Accra Ghana was used. A binomial logistic regression analysis was fitted to a data of 548 customers who were granted credit from January 2013 to December 2014. The results of the study revealed that six factors: $X 3$ (Marital Status); X7 (Dependents); X11 (Type of Collateral or Security); X13(Assessment); X15 (Duration); and $X 16$ (Loan Type) were statistically significant in the prediction of loan default payment with a predicted default rate of $86.67 \%$. It is therefore suggested that microfinance institutions adopt among others, the default risk model to ascertain the level of risk since it's relatively efficient and cost effective. There should also be up to date training for loan officers of microfinance institutions in order to improve on their assessment skills and methodology. The supervising body of microfinance institutions (Bank of Ghana) should also consider enacting laws that will ensure that all such institutions in Ghana are roped into centralized database to check multiple borrowing and also serve as an internal control measure for the sustainability of these institutions.
\end{abstract}

Keywords: Loan Default, Repayment, Microfinance Institutions, Logistic Regression 


\section{Introduction}

With almost thirty per cent of Ghanaians living below the poverty line, microfinance has been identified as an important means of providing financial services to the population. It is therefore not surprising that the country's present and past governments have perceived microfinance as central to achieving the greater goal of poverty reduction. Through microfinance, the various governments have aimed to provide the poor, who do not have access to the formal financial sector, with greater access to customized financial services. Robinson (2001) defined microfinance as small-scale financial services provided to people into petty businesses in both rural and urban communities. He further indicated that microfinance institutions are primarily established to provide business and consumer credit or bring financial services to poor and vulnerable groups in society with the ultimate goal of improving living standards or eradicating poverty. Micro financial institutions have had immense effects on real economic activity augmenting the operations of traditional financial houses and banks. Crockett (1996) asserts that disruption to loan supply might cause great changes in economic activity. The dynamics of economics is such that once interest rate begins to decline it becomes attractive to borrow from the banks for trading purposes as the returns will far outweigh the interest rate payments. Both sole traders and corporate bodies are encouraged to borrow from the bank. However should interests rise astronomically, people are rather encourage to save in the banks or buy fixed interest bonds whose returns are higher as compared to borrowing for capital investment.

Despite the risks associated with giving out loans, financial institutions are increasingly expanding their area of services. Currently there are institutions that employ full time personnel with sole duty of selling loans. They move from office to office appealing to the several public/private customers to subscribe to different loan packages. As a result of this, some private entrepreneurs have been able to expand their businesses and earn substantial profit. This process has ripple effect on the entire economy. If individuals establish businesses, they employ other people to help them in the day to day operations. According to Fama (1980) the banking institutions have advance loans to a wide category of customers. While some is given directly to corporate institutions, large portions to private individuals. The banks have various forms of valuation method to access the credit worthiness of the customers. This area is very critical if the banks are to be able to recover their loans when they are due. Most banks therefore have credit department that carry out all these important functions. However, despite the laudable ideas of these banks, there are quite a large number of customers who are unable to pay the interest that accrues on the loan. According to Balogun and Alimi (1990), loan default can be 
defined as the inability of a borrower to fulfill his or her loan obligation when due. High default rates in small and medium enterprises (SMEs) lending should be of major concern to policy makers in developing countries, because of its unintended negative impacts on SMEs financing. Microfinance institutions all over the world are faced with the challenge of loan default/delinquency. This situation has been so alarming to the extent that some financial institution have adopted some unconventional means of retrieving these loans. The sustainability of microfinance institutions depends largely on their ability to collect their loans as efficiently and effectively as possible. In other words to be financially viable or sustainable, microfinance institutions must ensure high portfolio quality based on $100 \%$ repayment, or at worst low delinquency/default, cost recovery and efficient lending.

\section{Objective(s) of the Study}

According to Boateng and Ampratwum (2011) the need for microcredit today is at its highest owing to the structure of the Ghanaian economy where majority (80\%) of the workforce is in the informal sector. The industry is considered inherently risky mostly due to the sector it serves. In most Microfinance Institutions (MFIs) the methods of deciding whether to grant a loan to an individual are usually mostly speculative and mostly based on the experience of previous decisions other than objective analysis. Over the years there has been a debate as to which method works best. The consensus among the experts is that no one method stands out, the choice is independent on other factors such as economic stability and the effectiveness and the dependability of the national database. The aim of this study is, therefore to determine the risk factors that influence loan default of customers in the microfinance sector and to develop model that links these factors to credit default for any customer in the sector.

\section{Theoretical framework}

\section{The Concept of Microfinance}

Microfinance is defined by Steel and Andah (2002) as small financial transactions with low income households and micro enterprises using nonstandard methodologies like character-based lending, group guarantee and short term repeated loans. Microfinance is provided by formal, semi-formal and informal financial agents. According to Otero (1994), microfinance creates access to productive capital for the poor, which together with human capital, addressed through education and training, and social capital, achieved through local organization building, enables people to move out of poverty. By providing material capital to a poor person, their sense of dignity is strengthened and this can help to empower them to participate in the 
economy and society (Otero, 1994). Credit granting non-governmental organizations, credit cooperatives and to some extent, a few rural banks have utilized microfinance as a sustainable mechanism to provide basic financial services to small-scale borrowers (Llanto, 2001). The wide network of lowincome clients of microfinance institutions proves that there is a great demand for credit by the poor and that they can successfully use these small loans to earn income (Llanto, 2001). The institutions involved in microfinance are either formal, semi-formal or informal. The formal microfinance institutions are larger businesses licensed to do financial intermediation through deposit mobilization and credit giving. They include the rural banks and the savings and loans companies. The semi-formal microcredit institutions include the non-governmental institutions involved in giving microcredit to the poorer members of the community. These include, susu firms, credit unions, and the like.

The underlying business principles and characteristics of these institutions influence their client bases and affect the repayment of the facilities they grant. The informal financial intermediaries have a cost advantage over the formal intermediaries in addressing the information asymmetry problem because they have access to devices and mechanisms to collect the necessary information about their clients. They frequently have more detailed knowledge of clients and their communities, and the local conditions in which they operate. As a result, they often face lower transaction cost in their service delivery. According to Aleem (1990), informal lenders mainly use the established relationship with borrowers as a screening and credit rationing mechanism. The formal intermediaries on the other hand enjoy economy of scale and can mobilize large amounts of deposits for lending. Institutions have typically been burdened with severe agency problems in dealing with peculiar risks, that is, the problems caused by costly and imperfect information such as adverse selection, moral hazard, and contract enforcement (Nissanke \& Aryeetey, 1998).

Karlan and Zinman (2004) used a randomized intervention to identify the extent of adverse selection and moral hazard in a South African credit market. They found out that about $40 \%$ of defaults in this market can be attributed to asymmetric information. Meyer and Nagarajan (2000) recommend that formal financial institutions must design their products and services according to the expected demand in rural areas, taking into consideration the presence of informal credit sources, and according to how costs could be recovered and profits could be generated. Such would then lead to a widened outreach. Essel (1996) has also noted that group-lending schemes (informal methodology) have been gradually gaining ground among the Rural Banks in Ghana and that the benefits reaped by the banks and their 
customers to date have been significant. He concludes by arguing that the banks should intensify efforts to establish group-based lending programmes.

\section{Loan Default Repayment}

Loan repayment default is the oldest and most prominent form of risk in the financial markets. If credit can be defined as "nothing but the expectation of a sum of money within some limited time”, then loan repayment default is the chance that this expectation will not be met. Caouette, Altman, \& Narayanan (1998) states that loan repayment default is as old as lending itself, which means that it dates back at least as far as 1800 BC.

A loan is delinquent when a payment is late (CGAP, 1999). A delinquent loan becomes a defaulted loan when the chance of recovery becomes minimal. Delinquency is measured because it indicates an increased risk of loss, warnings of operational problems, and may help to predict how much of the portfolio will eventually be lost because it never gets repaid. There are three broad types of delinquency indicators: collection rates, which measures amounts actually paid against amounts that have fallen due; arrears rates, measures overdue amounts against total loan amounts; and portfolio at risk rates which measures the outstanding balance of loans that are not being paid on time against the outstanding balance of total loans (CGAP, 1999).

Default occurs when a debtor has not met his or her legal obligations according to the debt contract. For example a debtor has not made a scheduled payment, or has violated a loan covenant (condition) of the debt contract (Ameyaw-Amankwah, 2011). A default is the failure to pay back a loan. Default may occur if the debtor is either unwilling or unable to pay their debt. A loan default occurs when the borrower does not make required payments or in some other way does not comply with the terms of a loan (Murray, 2011). Moreover, Pearson and Greef (2006) defined default as a risk threshold that describes the point in the borrower's repayment history where he or she missed at least three installments within a 24 month period. This represents a point in time and indicator of behaviour, wherein there is a demonstrable increase in the risk that the borrower eventually will truly default, by ceasing all repayments. The definition is consistent with international standards, and was necessary because consistent analysis required a common definition. This definition does not mean that the borrower had entirely stopped paying the loan and therefore been referred to collection or legal processes; or from an accounting perspective that the loan had been classified as bad or doubtful, or actually written-off. Loan default can be defined as the inability of a borrower to fulfill his or her loan obligation as at when due (Balogun and Alimi, 1990). 


\section{Methodology}

The design of the study is strictly quantitative. The study makes use of quantitative data; a historical data that contains the profile of customers of a microfinance institution was collected. Due to company policy, the name of the microfinance company was restricted and will be referred to in this paper as the MFI.

The target population included all customers of microfinance institutions in Ghana. However, Out of five institutions contacted, only one made available files and loan profiles for analysis. For many of the institutions contacted either their operational data was not adequately captured to fit the purpose of the study or the required data were unavailable. The analysis was thus restricted to one data source. The data set comprises of all individual loans disbursed from January 2013 to December 2014.

Given the sampling frame all the files of loans disbursed under the period of study were grouped into three; on time, not on time, default. On time: clients who were able to discharge their obligation within the time given for payment. Not on time: clients finished payment within one month after contract expired. Default: clients who have neither finished payment nor finished payment one month beyond the contract expiry period. The profiles of such clients; personal and loan characteristics were then captured with an SPSS database. Only those whose contracts were within the study period were captured.

\section{Definition of Variables}

$X 1=$ Age

Below is the predictor variables were considered for this study.

$X 2=$ Gender

$X 3=$ Marital Status

$X 4=$ Type of Business

$X 5=$ Residential Status

$X 6=$ Number of years at residence

$X 7=$ Dependents

$X 8=$ Purpose of loan

$X 9=$ Amount disbursed

$X 10=$ Date of disbursement

$X 11=$ Type of collateral (security)

$X 12=$ Guarantor

$X 13=$ Assessment

$X 14=$ Officer

$X 15=$ Duration

X16=Loan Type 


\section{Dependent variable construction and pre-processing}

The data preparation step deals with the choice and creation of the desired variables dependent and covariates. In this study a binary dependent variable default $(Y)$ was created.

$$
Y_{i}=\left\{\begin{array}{c}
1 \text { defaulted; if delayed payment is }>30 \text { days } \\
0 \text { non }- \text { defaulted; if delayed payment } \leq 30 \text { days }
\end{array}\right.
$$

This criterion is consistent with general definition of loan default. Since including all variables will make the model unnecessarily large, the principle of parsimony will justify small model. The researcher employed statistical procedures such as forward and backward selection processes to verify consistency of variables selected in the model.

\section{Analytical Tools}

The study makes use of the logistic regression model. Logistic regression is based on binomial probability theory. It is a mathematical modeling approach used in describing the relationship of several independent variables to a dichotomous dependent variable or a limited dependent variable. The logit function is employed because the dependent variable „defaulte is dichotomous, whereas the proposed covariates were mixture of continuous and categorical random variables. Thus the model was chosen over others due to the data structure and purpose. Also the independent variables need not be interval, nor normally distributed, nor linearly related, nor equal variance within each group. The logit model is a derivative of the odds function. The odd of a function is the ratio of the probability of success to that of failure. Thus

$$
\operatorname{Odds}(Y=1)=\frac{P(Y=1 / X=x)}{P(Y=0 / X=x)}
$$

Where $\operatorname{Odds}(Y=1)$ is the odds of defaul t; $P(Y=1)$ is the probability that default occurs given a set of explanatory variables and $P(Y=0)$ is the probability of non-default given set of explanatory variables.

If the odds of default is greater than one it means there is a higher probability of default compared to that of non-default. A value less than one indicate a higher probability of non-default than that of default.

Given the binary response variable (default or non-default), the probability distribution of the number of defaults in a given loan portfolio size, for given values of explanatory variables is binomial. Thus the probability that the number of default of a given portfolio size $\mathbf{n}$ is exactly equal to size $x$ is given by

$$
P(X=x)=\frac{n !}{x !(n-x) !} p^{x} q^{n-x}
$$


Where $q=P y(0)=$; probability of non-default). This means that given a portfolio size $n$ and probability of default $\mathrm{P}(\mathrm{Y}=1)$ from a financial institution, one can use the theorem to perform risk control analysis.

\section{Justification of Methodology}

The authors adopted the logistic regression analysis in the study in order to predict an outcome variable that is categorical from predictor variables that are categorical. This method was also used because having a categorical outcome variable violates the assumption of linearity in normal regression; since logistic regression deals with this problem by using a logarithmic transformation on the outcome variable which allows us to model a nonlinear association in a linear way. This methodology also expresses the linear regression equation in logarithmic terms.

\section{Results and discussions}

Table 1: Demographic Information of Survey Participants ( $n=548)$

\begin{tabular}{ccc}
\hline Variables & Frequency & Percentages \\
\hline Gender & & \\
Male & 195 & 35.6 \\
Female & 353 & 64.4 \\
Loan Repayment Status & & 74 \\
Paid & GHØ 2,021,984.9 & 26 \\
Arrears & GHC 710,427.12 \\
\hline
\end{tabular}

In all there are 548 clients within the period under study. Table 1 summarizes the socio-demographic information of the clients. From the table, 195 respondents which represent $35.6 \%$ were males and 353 of them which represent $64.6 \%$ were female. Concerning the loan repayment status, in all as at December 2014, the company had disbursed GHC 2,732,412. Out of this GHC 2,021,984.9 which represents $74 \%$ had been paid as at the end of December, 2014 whilst the rest GHC 710,427.12 representing 26\% of the portfolio value was in arrears. 


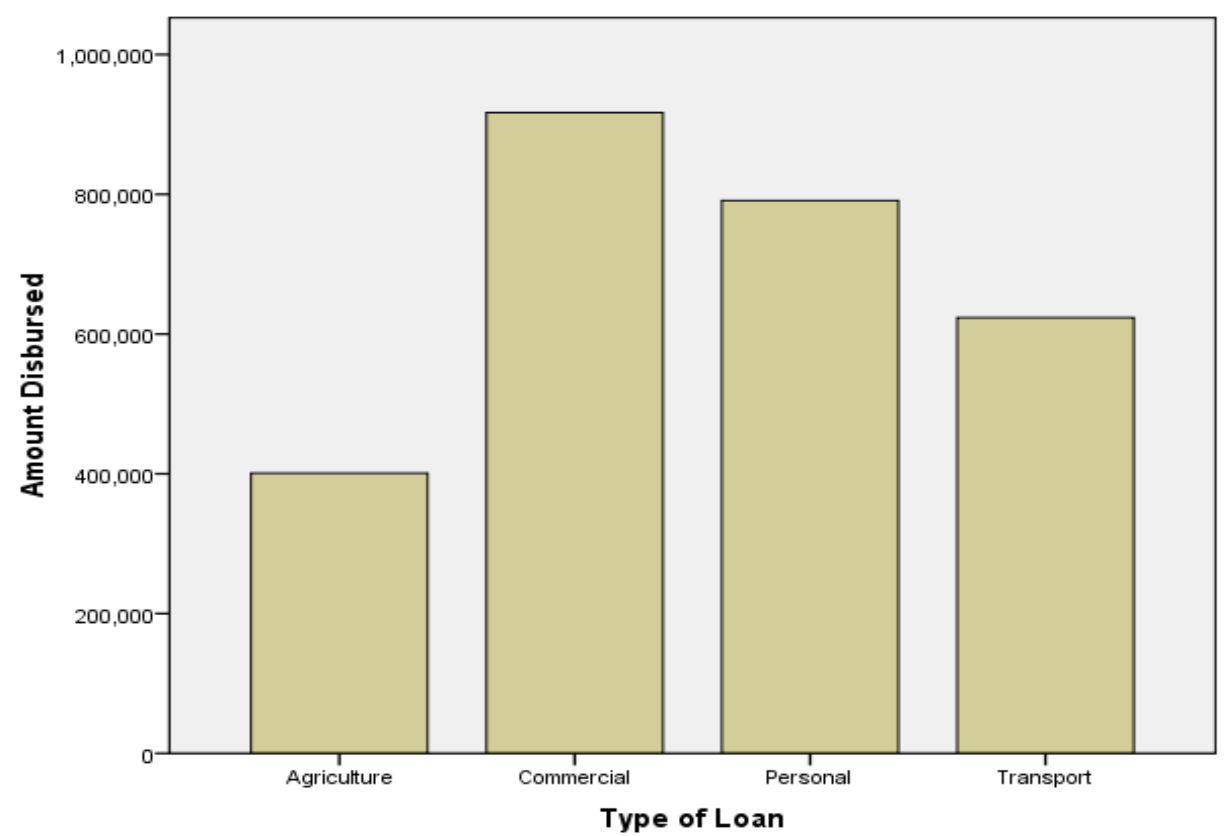

Figure 1: A Bar Graph Showing the Sum of Money Disbursed Against Type of Loan

Figure 1 above shows the distribution of the amount of money disbursed to customers by the type of loan accessed. It can be seen that among the type of loans, commercial loan was given the highest total amount approved to customers which is GHC 917,000; followed by personal loan which also recorded GHC 791,001. Transport loan was the third highest with a total amount approved as GHC 623,412. Finally, agricultural loan recorded the least amount approved which was GHC 401,000.

Table 2: Independence of Type of Loan versus Repayment Status

\begin{tabular}{ccccc}
\hline Count & & \multicolumn{2}{c}{ Default Status } & Total \\
\hline & & No & Yes \\
\hline \multirow{2}{*}{ Loan type } & Agricultural & 47 & 24 & 71 \\
& Commercial & 68 & 35 & 103 \\
& Personal & 196 & 71 & 277 \\
& Transport & 65 & 32 & 97 \\
\hline Total & & 376 & 172 & 548 \\
\hline Chi-Square Test & Value & df & Asymp. Sig. (2-sided) \\
\hline Pearson Chi-Square & 16.02 & 3 & \multicolumn{3}{c}{0.01} \\
N of Valid Cases & 548 & \multicolumn{3}{|c}{}
\end{tabular}

The count part of the table shows that, about $31.39 \%$ of the customers end up defaulting in the repayment of loans depending on the type of loan 
granted. The chi-square test of independence part also shows that the test is significant since the asymptotic significance of 0.01 is less than 0.05 ; and so the ability of a customer to default or otherwise of a loan depends on the Loan Type applied for.

Table 3: Logistics Regression Estimates of Factors Influencing Default Payment

\begin{tabular}{ccccccccc}
\hline & & & & & & & & \multicolumn{2}{c}{$95.0 \%$ C.I.for EXP(B) } \\
\cline { 7 - 9 } X1 & 0.171 & 0.218 & 0.616 & 1 & 0.433 & 1.187 & 0.774 & 1.821 \\
X2 & -0.274 & 0.170 & 2.601 & 1 & 0.107 & 0.760 & 0.545 & 1.061 \\
X3 & -0.843 & 0.200 & 17.693 & 1 & 0.000 & 0.430 & 0.291 & 0.638 \\
X4 & -0.238 & 0.266 & 0.801 & 1 & 0.371 & 0.788 & 0.468 & 1.327 \\
X5 & 0.008 & 0.167 & 0.002 & 1 & 0.963 & 1.008 & 0.727 & 1.398 \\
X6 & 0.293 & 0.223 & 1.727 & 1 & 0.189 & 1.341 & 0.866 & 2.076 \\
X7 & 0.952 & 0.214 & 19.861 & 1 & 0.000 & 2.591 & 1.704 & 3.937 \\
X8 & -0.256 & 0.211 & 1.469 & 1 & 0.226 & 0.774 & 0.512 & 1.171 \\
X9 & -0.384 & 0.267 & 2.072 & 1 & 0.150 & 0.681 & 0.404 & 1.149 \\
X10 & 0.149 & 0.270 & 0.307 & 1 & 0.580 & 1.161 & 0.685 & 1.969 \\
X11 & 0.871 & 0.151 & 1.652 & 1 & 0.000 & 2.389 & 0.613 & 1.107 \\
X12 & 0.146 & 0.140 & 1.096 & 1 & 0.295 & 1.158 & 0.880 & 1.523 \\
X13 & 0.678 & 0.298 & 5.174 & 1 & 0.023 & 1.971 & 0.649 & 1.657 \\
X14 & 0.036 & 0.239 & 0.023 & 1 & 0.880 & 1.037 & 1.098 & 3.535 \\
X15 & 0.737 & 0.242 & 9.293 & 1 & 0.002 & 2.091 & 1.301 & 3.359 \\
X16 & -0.818 & 0.190 & 18.606 & 1 & 0.000 & 0.441 & 0.304 & 0.640 \\
Constant & 0.294 & 1.688 & 0.030 & 1 & 0.862 & 1.342 & & \\
\hline
\end{tabular}

Table 3 shows the result of logistic regression estimates of the various factors influencing loan payment defaults. The significant value of the Wald statistics for each independent variable indicates the contribution or importance of each predictor variable $(\mathrm{P}<0.05)$.

From the table, column six (6) determines the variables that contribute significantly to the predictive ability of the model at 0.05 level of significance. These variables are, $X 3$ (Marital Status), $X 7$ (Dependents), $X 11$ (Type of collateral or security), X13(Assessment), X15 (Duration), and X16 (Loan type). This findings support the research results of Dinh and Kleimeier (2007) which indicated that the collateral value could also be a proxy for the borrowers ${ }^{\text {ee }}$ financial wealth since it is significantly positive correlated with the borrowers's income. It is also consistent with the observations of Dinh and Kleimeir (2007) who intimated that, marital status affects the borrower's level of responsibility, reliability, or maturity. The probability of default is higher for the married than single borrowers. They discover that the marital status is typically related to number of dependents which in turn reflects 
financial pressure on the borrower and borroweres ability to repay a loan. Thus the logistic function is given by the equation (2) below:

$$
P(\text { Default }) \quad=\frac{1}{1+e^{-(.294-0.843 X 3+0.952 X 7+0.871 X 11+0.678 X 13+0.737 X 15-0.818 X 16)}}
$$

Furthermore, the odd ratio $(\operatorname{Exp}(\beta))$ for the significant factors, shows the increase (or decrease if the ratio is less than one) in odds of being in one outcome category (default or no default) when the value of the predictor increases by one unit. From table 2, the odds or risk of customer defaulting in repayment of loan, is 0.430 for $X 3$ (Marital Status). This indicates that, the risk of a customer defaulting in a loan repayment is 0.430 times higher for a customer who is married and with children than for customers who are single, all other factors being equal. For $X 7$ (Dependents), the odd ratio of 2.591 indicates that risk of customer with larger number of dependents, is 2.591 times more likely to default in repayment as compared with those with least number of dependents, all other factors being equal. For $X 11$ (Type of collateral or security), the odd ratio of 2.389 indicates that the risk of a customer defaulting in repayment of loans is 2.389 times higher for a customer who used collateral than for a customer who used personal guarantee, all other factors being equal.

Also for X13 (Assessment) the odd ratio is 1.971 which means that for any wrong assessment of clients before loan are granted to them, the risk of defaulting increases by 1.971, all other factors being equal. Furthermore, for X15 (Duration), the odd ratio of 2.091 indicates that the risk of a customer defaulting in loan repayment is 2.091 times higher for a customer who has been given shorter duration to pay back than those who has been given longer duration, all other factors being equal. Finally, the odd ratio of 0.441 for X16 (Loan type) indicates that, for any type of loan granted, the risk of defaulting decreases by a factor of 0.441 , all other factors being equal.

\section{Conclusion}

The study revealed that six (6) factors; $X 3$ (Marital Status), $X 7$ (Dependents), X11 (Type of collateral or security), X13(Assessment), X15 (Duration), and $X 16$ (Loan type) were statistically significant in the prediction of loan default payment with a predicted default rate of $86.67 \%$. This indicates that there is probability that $86.67 \%$ of customers, with the given characteristics are likely to default their loan repayment.

Therefore, there is a need for Micro-financial Institutions to adopt among others the default risk model to ascertain the level of risk since it's relatively efficient and cost effective. There should also be adequate training for Loan officers in the MFI in order to improve on their assessment skills and methodology. 
Finally, Bank of Ghana should consider enacting a law that will ensure that all MFIs in Ghana are put on a centralized database to check multiple borrowing and also serve as an internal control measure for sustainable MFIs in Ghana.

\section{Limitations and recommendations}

An obvious limitation that had a significant impact on the results obtained from this study is the fact that only one organization was sampled from an industry of 468 players (microfinance institutions: https://www.bog.gov.gh; retrieved on January 4, 2016). This is coupled with the fact that very little information in terms of organized literature exists in Ghana on the operations of these non traditional banking institutions. It is therefore recommended that other researchers can delve deeper into this very important research area in order to scoop out further facts about loan defaults in the microfinance industry in Ghana.

\section{References:}

Abratt, \& Russell. (1999). Relationship Marketing in Private Banking South Africa. The International Journal of Bank Marketing, 17(1):5-6.

Addo. (2014). In G. B. survey, The Future of Banking in Ghana... What's next?

Aleem, I. (1990). Imperfect Information, Screening, and the Costs of Informal Lending: A Study of a Rural Credit Market in Pakistan. World Bank Economic Review, 4(3):329-349.

Ameyaw-Amankwah, I. (2011). Causes and effects of loan defaults on the profitability of Okomfo Anokye Rural Bank. Thesis, unpublished KNUST.

Athanassopoulos, D. (2000). Customer satisfaction cues to support market segmentation and explain switching behaviour. Journal of Business Research, Vol. 47, pp. 191-207.

Balogun , E., \& Alimi, A. (1990). Loan Delinquency Among Small Farmers in Developing Countries: A Case Study of the Small-Farmer Credit Programme in Lagos State of Nigeria,. CBN Economic and Financial Review, 26(3).

Balogun, , E., \& Alimi, A. (1990). Loan Delinquency Among Small Farmers in Developing Countries: A Case Study of the Small-Farmer Credit Programme in Lagos State of Nigeria. CBN Economic and Financial Review, 26(3).

Berry, L. (1995). Relationship marketing of services-growing interest, emerging perspectives. Journal of the Academy of Marketing Science, Vol. 23 No. 4, pp. 236-45.

Bloemer, J., Ko de Ruyter, \& Peeters, P. (1998). “Investigating drivers of bank loyalty: the complex relationship between image, service quality and 
satisfaction’’. International Journal of Bank Marketing, Vol. 16 No. 7, pp. 276-86.

Boateng , C., \& Ampratwum, E. (2011). The Informal Sector in Ghana . Ghana Office: Friedrich Ebert Stiftung.

Bounsaythip , \& Rinta-Runsala . (2001). Overview of Data Mining for Customer Behavior Modeling, Report no. 1. . VTT Information Technology, pp. 1-53.

Caouette, J., Altman, E., \& Narayanan, P. (1998). Managing Credit Risk: The next Great Financial Challenge. Indianapolis: John Wiley \& Sons, Inc.

CGAP. (1999). Measuring microcredit delinquency: Occasional paper no. 3. CGAP Secretariat 1818 h street: Government printers.

Colgate, M., \& Hedge, R. (2001). An Investigation into the Switching Process in Retail Banking Services. International Journal of Bank Marketing, Vol. 19, No. 4/5, pp. 201-212.

Colgate, M., Stewart, K., \& Kinsella, R. (1996). Customer Defection: A Study of the Student Market in Ireland. The International Journal of Bank Marketing.

Crockett. (1996). The theory and Practice Financial Stability. Economist Vol. 144, 4:531-568.

Dinh, T., \& Kleimeier, S. (2007). A Credit Scoring Model for Vietnam ${ }^{\text {ee }}$ Retail Banking Market, . International Review of Financial Analysis, Vol. 16, Issue 5, p.571-495.

Essel, T. (1996). “The Impact of Rural Banks' Lending Operations on Rural Development: A Case Study of Kakum Rural Bank”. . An Unpublished M.Phil. Thesis, University of Cape Coast, Cape Coast.

Fama, E. (1980). Banking in the theory of Finance. Journal of Monetary Economics, Vol. 6;1:39-57.

Gerrard, P., \& Cunningham, J. (2004). Consumer Switching Behaviour in the Asia Banking Market. The Journal of Service Marketing, Vol. 18, No. 2/3, pp. 215.

Heskett, T., Jones, T., Loveman, G., \& Sasser Jr, J. (1994). Putting the service-profit chain to work. Harvard Business Review.

Hull. (2002). Foreign-owned Banks: Implications for New Zealand's Financial Stability. Discussion Paper Series, DP2002(5).

Jacoby, J., \& Kyner, D. (1973). Brand loyalty vs. repeat purchasing behaviour. Journal of Marketing Research, 1:9.

Jones, M., Mothersbaugh, D., \& Beatty, S. (2000). Switching barriers and repurchase intentions in services . Journal of Retailing, 76(2), 259-274.

Kamakula. (1998). Marketing Segmentation: Conceptual and Methodological Foundations. Boston: Kluwer Academic Publishers.

Kaplan , \& Narayanan. (2001). Measuring and Managing Customer Profitability. Journal of Cost Management, 5-15. 
Karlan, D., \& Zinman, J. (2004). "Observing Unobservable: Identifying Information Asymmetries with a Consumer Credit Field Experiment". Princeton Economics Department working paper.

Konkurrensvert, 2. (2009). Konkurrensen i Sverige: Åtgärder för bättre konkurrens. [electronic]Available via: http://www.kkv.se/upload/Filer/Trycksaker/Rapporter/rap_2009-.

Krishnan, M., Ramaswamy, V., Meyer, C., \& Damien, P. (1999). Customer satisfaction for financial services: the role of products, services, and information technology. Management Science, Vol. 45 No. 9, pp. 1194-209. Lariviere, \& Poel. (2004). Investigating the role of product features in preventing customer churn, by using survival analysis and choice modelling: the case of financial services. Expert Systems with Applications, Vol. 27, pp. 277-85.

Liu. Chung- Tzer, Guo. Yi-Maggie , \& Lee. Chia-Hui. (2010). The effects of relationship quality and switching barriers on customer loyalty. International Journal Of Information Management, 1-9.

Llanto, G. (2001). "Sustainable Rural Finance: Policy and Design Issues". PIDS Policy Notes No. 2001-04. Makati City, Philippines: Philippine Institute for Development Studies.

Looy, B., Gemmel, P., \& Dierdonck, R. (2003). Services Management: an integrated approach, 2nd Edition,. Essex: Prentice Hall.

Meyer, R., \& Nagarajan, G. (2000). "Rural Financial Markets in Asia: Flagships and Failures". Paper Presented at the Mini-Symposium on Building Financial Markets in Developing Countries for Tomorrow's Agriculture: Status, Reforms and Innovations. XXIV International Conference of Agricultural Economists. Berlin, Germany.

Mittal, V., William, T., \& Patrick, M. (1998). The asymmetric impact of negative and positive attribute-level performance on overall satisfaction and repurchase intentions. Journal of Marketing, 62: 33-47.

Murray, J. (2011). Default on a loan. United States Business Law and Taxes Guide.

Nguyen, N., \& Le Balnc, G. (1998). The mediating role of corporate image on customers' retention decisions: an investigation in financial services. International Journal of Bank Marketing, Vol. 16 No. 2, pp. 52-65.

Nissanke, M., \& Aryeetey, E. (1998). Financial Integration and Development in Sub-Saharan Africa, Liberalisation and Reform in subSaharan Africa. London and New York:: Routledge.

Otero, M. (1994). "The Evolution of Nongovernmental Organizations Toward Financial Intermediation." In Maria Otero and Elisabeth Rhyne (eds.), The New World ofMicro enterprise Finance: Building Healthy Institutions for the Poor. West Hartford, CT: Kumarian Press. 
Pearson, R., \& Greef, M. (2006). Causes of Default among Housing Micro Loan Clients . South Africa: FinMark Trust Rural Housing Loan Fund, National Housing Finance Corporation and Development Bank of Southern Africa.

Perner, L. (2006). CONSUMER BEHAVIOR. The pyschology of Marketing. Reichheld, \& Kenny. (1990). The Hidden Advantages of Customer Retention. Journal of Retail Banking, 7(4):19-23.

Reinartz, \& Kumar. (2000). "On the profitability of long-life customers in a no contractual setting: an empirical investigation and implications for Marketing', Journal of marketing, Vol. 64, pp. 17-35.

Robinson. (2001). The microfinance revolution. Washington DC: World Bank Publications.

Rosario , \& Foxall . (2006). Positive vs. negative switching barriers: The influence of service consumers' need for variety. Journal of Consumer Behavior, 5, 367-379.

Steel, W., \& Andah, D. (2002). Review of Rural Microfinance Regulations in Ghana: Implications for Development and Performance of the Industry. Washington D.C.: World Bank.

Wirtz , J. (2003). Halo in customer satisfaction measures: The role of purpose of rating, number of attributes and customer involvement. International Journal of Service Industry Management, 14(1), 96-119.

Yi. (1990). A critical review of consumer satisfaction. American Marketing Association, Chicago, IL : 68-123.

Zeithmal, V., Berry, L., \& Parasuraman, A. (1996). The behavioural consequences of service quality . Journal of Marketing, 60(2): 31-46.

Zikiene, K., \& Bakanauskas, A. (2006, October 8). Research of Factors influencing loyal customer switching behavior. Retrieved from http://www.mediastudies.lt/sites/default/files/Bakanauskas\%20Zikiene.pdf 